\title{
Oral manifestations of leprosy
}

\author{
A. SCHEEPERS* $\ddagger$ J. LEMMER $\dagger \&$ J. F. LOWNIE* \\ $*$ Department of Maxillofacial and Oral Surgery; and $\dagger$ Department \\ of Oral Medicine and Periodontology, Oral and Dental Teaching \\ Hospital of the Witwatersrand, University of the Witwatersrand, \\ Johannesburg, Republic of South Africa
}

\section{Accepted for publication 9 October 1992}

Summary A total of 37 out of 187 patients with leprosy had oral lesions. All were biopsied. Oral lesions were found most frequently in patients with lepromatous leprosy. Prevalence of oral lesions was higher in males than in females $(73 \%: 27 \%)$. Oral lesions were recorded on the WHO topographical map, and in most cases $(92 \%)$ several topographical locations were affected, including hard palate in all cases. Topographical locations affected increase with age; males are more extensively affected than females $(p=0.001)$; and patients with oral lesions who reported affected family members (11 out of 37 ) had more extensive oral lesions than those who did not. In 27 cases with oral lesions histopathological diagnosis was possible.

\section{Introduction}

The current estimated prevalence of leprosy in Africa as a whole is about 3.14/1000 of the population. This is more than double the figure of $1 \cdot 56 / 1000 \mathrm{for}$ Asia, and far greater than the figures of $0 \cdot 46 / 1000$ for the Americas combined and 0.02/1000 for Europe. ${ }^{1,2}$

In the Republic of South Africa there are no accurate prevalence figures available; but incidence figures have declined strikingly in the last 55 years from 8/100,000 in 1935 to about $0 \cdot 2 / 100,000$ in 1990,3, Mars PW personal communication and it may be said with confidence that the prevalence is very much lower than for Africa as a whole.

\section{Materials and methods}

Over a 2-year period, 187 patients newly admitted or readmitted for treatment of leprosy at Westfort Hospital, near Pretoria, South Africa, were examined-110 were male and 77 were female (Table 1).

$\ddagger$ Correspondence: Dr A. Scheepers, P.O. Box 140, 2050 WITS, Republic of South Africa. 
Table 1. Number of patients with the various subtypes of leprosy

\begin{tabular}{lrrr}
\hline $\begin{array}{l}\text { Type of } \\
\text { leprosy* }\end{array}$ & Male & Female & Total \\
\hline TT & 0 & 0 & 0 \\
BT & 45 & 23 & 68 \\
BB & 18 & 13 & 31 \\
BL & 19 & 18 & 37 \\
LL & 28 & 23 & 51 \\
Total & 110 & 77 & 187 \\
\hline
\end{tabular}

* TT, 'True' tuberculoid leprosy; BT, borderline tuberculoid leprosy; BB, 'true' borderline leprosy; and BL, borderline lepromatous leprosy.

In every case in which oral lesions were found, biopsies were done with the consent of the patients. Information about the patients and the locations of the oral lesions were recorded on a form which incorporated the WHO topographical map for oral lesions (Figure 1).

\section{Results}

Out of 187 patients, 37 had oral lesions. According to the diagnoses at admission, oral lesions were strikingly more prevalent in patients with lepromatous leprosy (Table 2), and in males (27 males, 10 females).

The ages of patients with oral lesions ranged from 14 to 59 with a peak of distribution in the $30-39$ age group.

In objectively evaluating the oral lesions, the number of WHO topographical locations (Figure 1) affected was used as the criterion for the extent of the lesions; and the presence or absence of ulceration as the criterion for the severity of the lesions.

The number of affected locations recorded on the WHO topographical map increases with age; but the oral ulceration occurred most often in the 30-39 age group.

Judged by the number of WHO topographical locations affected, males had significantly more extensive oral involvement ( $p=0 \cdot 001)$; but there was not a statisticallysignificant difference in oral ulceration between males and females $(p=0 \cdot 056)$.

Compared to those who did not have a family member with leprosy, those patients who did were significantly more extensively affected (number of WHO topographical sites affected) $(p=0 \cdot 001)$ although the difference in severity of the oral lesions (ulceration) was not statistically significant. Figure 1 is the composite picture which emerged when 37 WHO topographical maps for the 37 patients with oral lesions were combined. Locations within the oral cavity affected in order of frequency are illustrated in Figure 1.

Clinical photographs of representative oral lesions are shown in Figures 2 and 3. Aspects of the histology of the oral lesions are summarized in Table 3.

Epithelial atrophy was noted only in patients with lepromatous leprosy. Hyperkerato- 


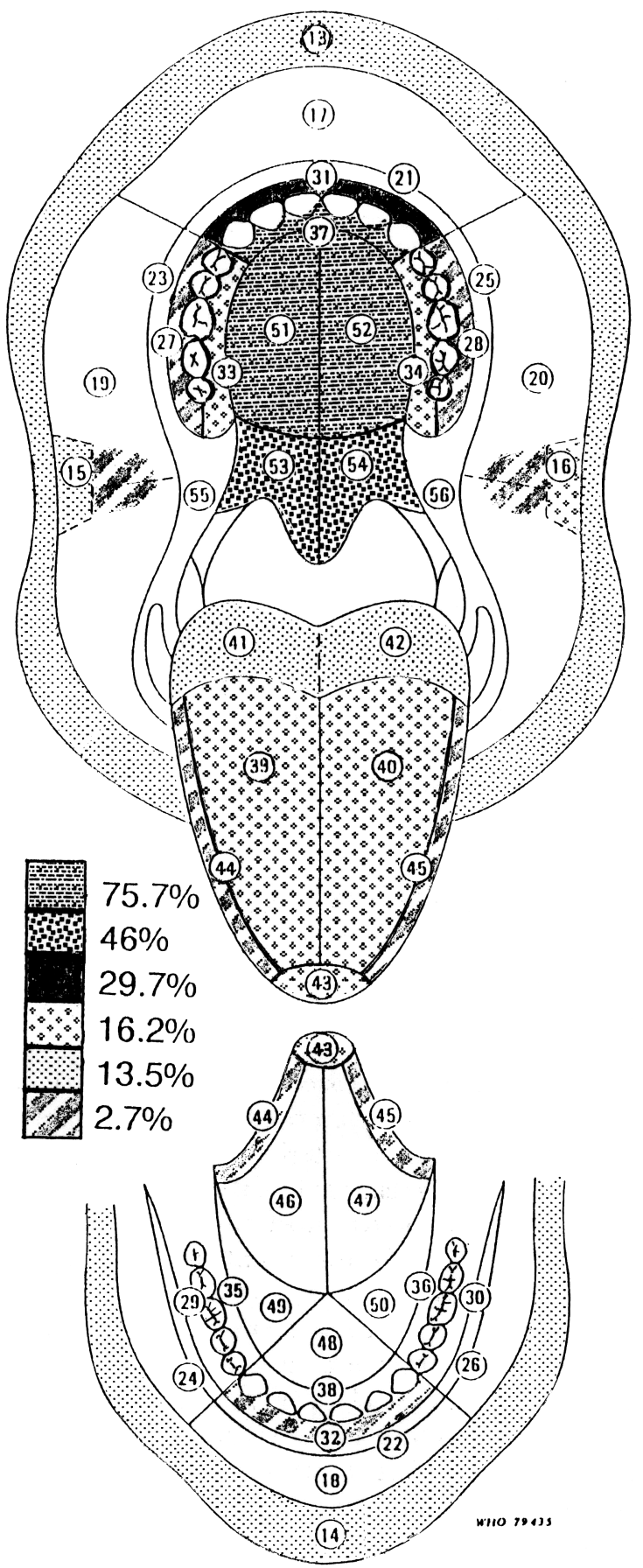

Figure 1. Frequency of involvement of each WHO topographical location as a percentage of the number of patients with oral lesions. 
Table 2. Prevalence of oral lesions

\begin{tabular}{lccr}
\hline $\begin{array}{l}\text { Type of } \\
\text { leprosy }\end{array}$ & $\begin{array}{c}\text { Patients } \\
\text { examined }\end{array}$ & $\begin{array}{c}\text { Patients with } \\
\text { oral lesions }\end{array}$ & $\%$ with \\
\hline TT & 0 & 0 & 0 \\
BT & 68 & 3 & $4 \cdot 4$ \\
BB & 31 & 2 & $6 \cdot 5$ \\
BL & 37 & 3 & $8 \cdot 1$ \\
LL & 51 & 29 & $56 \cdot 9$ \\
Total & 187 & 37 & $19 \cdot 8$ \\
\hline
\end{tabular}

* See Table 1 for key.

sis was observed in 5 of the 8 cases in the borderline subgroups, but in only 5 of 29 cases in the lepromatous leprosy subgroup.

Only 1 oral lesion showed an infiltrate-free subepithelial zone, in contrast to skin lesions where this is the rule. Heavy infiltrations of macrophages, lymphocytes and plasma cells were a constant observation in the oral lesions of lepromatous leprosy, and numerous acid-fast bacilli were usually seen.

In 27 of the 37 oral biopsy specimens, Mycobacterium leprae bacilli were seen, permitting a definite histopathological diagnosis. All but 2 of the remaining cases showed varied histological features consistent with the clinical diagnosis, but not in themselves diagnostic. Oral lesions were classified on clinicohistopathological evidence as lepromatous response (30 cases), Type 1 lepra reaction ( 5 cases), Type 2 lepra reaction ( 2 cases).

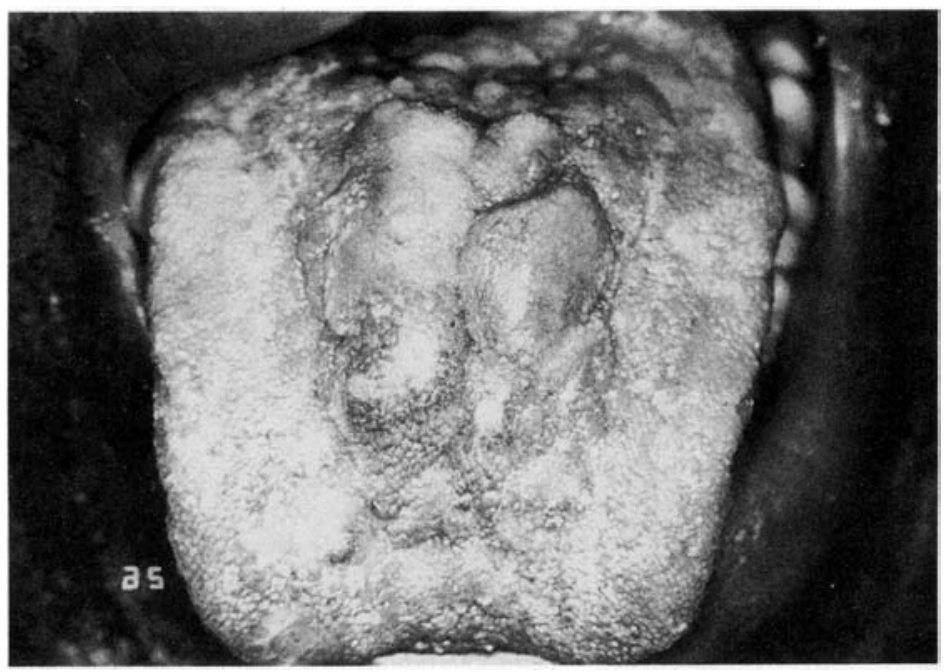

Figure 2. Nodular lesions of dorsum of tongue in lepromatous leprosy. 


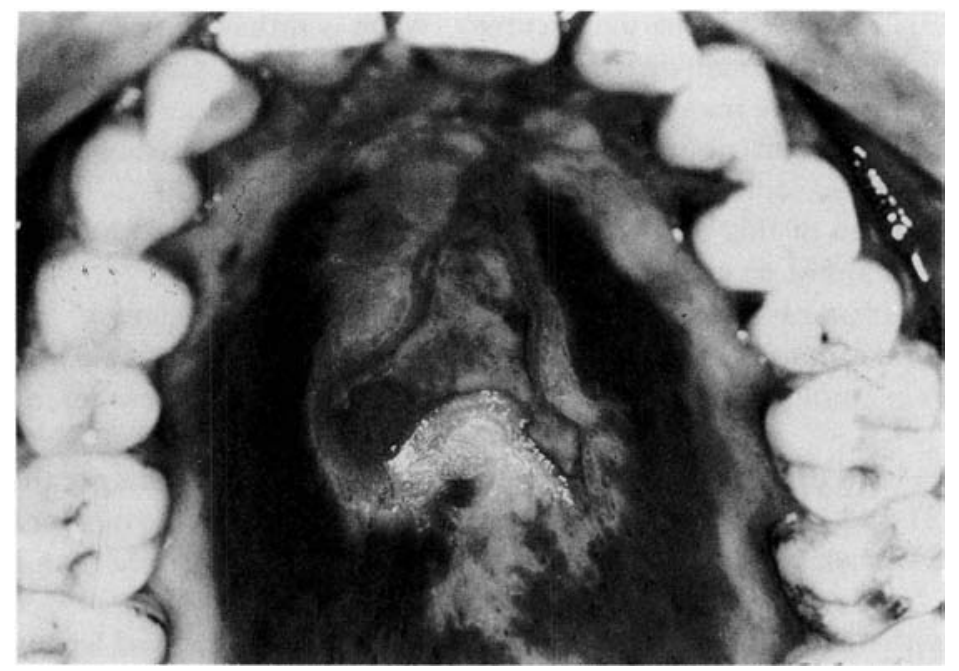

Figure 3. Ulceration of the anterior and mid-palate.

Table 3. Histological features of the oral lesions

\begin{tabular}{|c|c|c|c|c|c|}
\hline \multirow{2}{*}{$\begin{array}{l}\text { Aspect of histology } \\
\text { (Diagnosis* and } \\
\text { number of cases) }\end{array}$} & \multicolumn{4}{|c|}{ Number of cases } & \multirow[b]{2}{*}{ Total } \\
\hline & BT (3) & $\mathrm{BB}(2)$ & BL (3) & LL (29) & \\
\hline \multicolumn{6}{|l|}{ Epithelium } \\
\hline Normal & 2 & 0 & 3 & 10 & 15 \\
\hline Atrophy & 0 & 0 & 0 & 9 & 9 \\
\hline Hyperplasia & 1 & 2 & 0 & 9 & 12 \\
\hline Hyperkeratosis & 2 & 1 & 2 & 5 & 10 \\
\hline \multicolumn{6}{|l|}{ Connective tissue } \\
\hline Normal & 1 & 1 & 0 & 2 & 4 \\
\hline Infiltrate-free & 0 & 0 & 0 & 1 & 1 \\
\hline \multicolumn{6}{|l|}{ Sube pithelial zone } \\
\hline Macrophages & 1 & 1 & 2 & 27 & 31 \\
\hline Lymphocytes/Plasma cells & 2 & 1 & 3 & 21 & 27 \\
\hline \multicolumn{6}{|l|}{ Bacilli } \\
\hline None & 3 & 2 & 1 & 4 & 10 \\
\hline Few & 0 & 0 & 0 & 2 & 2 \\
\hline Moderate & 0 & 0 & 0 & 1 & 4 \\
\hline Numerous & 0 & 0 & 2 & 19 & 21 \\
\hline
\end{tabular}

* See Table 1 for key.

\section{Discussion}

None of the oral lesions may be said to be clinically entirely characteristic or pathognomonic of leprosy; but advanced lesions like those shown in Figures 2 and 3 
should certainly raise the suspicion of leprosy. What is rather constant, as borne out by the topographical locational distribution (Figure 1), is the palatal position and the bilateral symmetry of the majority of the lesions. ${ }^{4}$

This rather specific distribution of the orallesions has speculatively been attributed to the preference of the leprosy bacillus for temperatures below $37^{\circ} \mathrm{C} . .^{5,6}$ The apparently simple confirmation of this postulation has to date been frustrated by the fact that the leprosy bacillus cannot be cultured in vitro. ${ }^{7}$

Oral lesions are considered to be a manifestation of advanced leprosy ${ }^{8-10}$ and as female patients with oral lesions constituted only $5 \cdot 4 \%$, while male patients constituted $14 \cdot 4 \%$ of all the patients examined, it may be that the females seek treatment earlier in the course of the disease.

In patients with oral lesions, the females were also slightly younger than the males (averages of 31 and 34.7 years, respectively). The presentation by younger females with less-advanced disease may reflect a greater concern with appearance than is the case in males.

Patients with oral lesions and with family members who also had leprosy, in general were more severely affected than those whose family members were free of the disease. This favours the possibility of an hereditary predisposition to leprosy, although the published evidence for this is inconclusive. ${ }^{1}$

Mukherjee, Girdhar \& Desikan"l described the histopathology of lesions of the tongue in a small series of 8 patients with leprosy. They reported none with the bacilli-free subepithelial zone typically reported in skin lesions. ${ }^{1}$ The same was true of the present study with the exception of a single case. The proximity to the epithelium of innumerable micro-organisms in the lamina propria as well as their presence in the epithelium itself supports the contention that bacilli may enter the oral fluids, with obvious epidemiological implications in ethnic cultures where spitting is a common habit. ${ }^{11,12}$

Of Mukherjee's cases, ${ }^{11} 4$ had epithelial hyperplasia, which is also in contrast to skin lesions where atrophy and flattening of the epithelium-corium interface are observed. In the present series, epithelial hyperplasia was a common finding with 12 cases noted either as the primary histological feature or as an associated feature (Table 3 ).

In general, the oral lepromatous granulomata in the present series show the same histopathological features of inflammatory infiltrate and striking bacillary population as described in the literature. ${ }^{9,11}$

Lesions related to the Type 1 lepra reaction in the skin are known to desquamate after some time. The hyperkeratosis noted in 3 of the oral lesions in patients with Type 1 lepra reactions in this series may be analogous to desquamation of the skin.

Where leprosy is endemic, the increasing prevalence of AIDS, which is expected to be associated with progressive, fulminating leprosy, ${ }^{13}$ may also bring about a pattern of oral lesions different to that which we have described.

\section{References}

1 Jopling WH. Handbook of Leprosy, 3rd Ed. London: Heinemann, 1986; 5: 16.

2 World Health Organization. A Guide to Leprosy Control. 3rd Ed. Geneva: WHO Publications; 1988: 3.

3 Schulz EJ, Pentz HHL. Leprosy control in South Africa. Lepr Rev, 1970; 41: 15-19.

${ }^{4}$ Girdhar BK, Desikan K V. A clinical study of the mouth in untreated lepromatous patients. Lepr Rev, 1979; 50: $25-35$. 
${ }^{5}$ Brand PW. Temperature variation and leprosy deformity. Int J Lepr, 1959; 27: 1-7.

6 Reichart P, Ananatasan T, Reznik G. Gingiva and periodontium in lepromatous leprosy. J Periodontol 1976; 47: 455-460.

7 Hutchinson J. Cultivation of the leprosy organism. Int J Dermatol, 1990; 29: 189.

8 Lighterman I, Watanabe Y, Hidaka T. Leprosy of the oral cavity and adnexa. Oral Surg Oral Med Oral Pathol, 1962; 15: 1178-1194.

9 Reichart P. Facial and oral manifestations of leprosy. Oral Surg Oral Med Oral Pathol, 1976; 41: 385-399.

10 Prabhu SR, Daftary DK. Clinical evaluation of oro-facial lesions of leprosy. Odontostomatol Trop, 1981; 4: 83-95.

11 Mukher jee A, Girdhar BK, Desikan KV. Histopathology of tongue lesions in leprosy. Lepr Rev, 1979; 50: $37-$ 43.

12 Alfieri N, Fleury RN, Opromolla DVA, Ura S, de Campos I. Oral lesions in borderline and reactional tuberculoid leprosy. Oral Surg Oral Med Oral Pathol, 1983; 55: 52-57.

13 Schulz EJ. Congress report: 13th International Leprosy Congress, The Netherlands. S Afr MedJ, 1989; 76: 233-234.

Lepr Rev (1993) 64, 37-43

\section{Manifestations buccales de la lèpre}

\section{A. Scheepers, J. Lemmer et J. F. Lownie}

Résumé Un total de 37 sur 187 patients atteints de lèpre a présenté des lésions buccales. Une biopsie a été effectuée sur toutes ces lésions. Les lésions buccales étaient le plus souvent observées chez les patients atteints de lèpre lépromateuse. La fréquence des lésions buccales étaient plus élevées chez les hommes que chez les femmes (73\% contre $23 \%)$. Les lésions buccales ont été marquées sur la carte topographique de l'OMS, et dans la plupart des cas $(92 \%)$ plusieurs localisations étaient affectées, y compris le palais dans tous les cas. Les localisations topographiques affectées augmentent avec l'âge; les hommes sont plus affectés que les femmes $(p=0,001)$; et les patients qui ont signalé que d'autres membres de leur famille étaient affectés (1 l sur 37) avaient des lésions plus étendues que ceux qui n'ont rien signalé. Dans 27 cas présentant des lésions buccales le diagnostic histopathologique a été possible.

\section{Manifestaciones orales de la lepra}

\section{A. Scheepers, J. Lemmer y J. F. Lownie}

Resumen Un total de 37 de 187 pacientes con lepra sufría de lesiones orales. Se hizo una biopsia en todos. Se encontraron las lesiones orales con más frecuencia en los pacientes con lepra lepromatosa. La frecuencia de lesiones orales era más en hombres que en mujeres $(73 \%: 27 \%)$. Se registró la frecuencia de las lesiones orales en el plano topográfico de la OMS y, en la mayoría de casos $(92 \%)$, varías situaciones topográficas fueron afectadas, paladar duro en la mayoría de los casos. Las situaciones topográficas afectadas aumentan con la edad; los hombres están más extensamente af ectados que las mujeres $(p=0,001)$; y los pacientes con lesiones orales que informaron de parientes afectados ( 11 de los 37) tuvieron lesiones orales más extensas que los que no lo hicieron. En 27 casos de lesiones orales, fue posible un diagnóstico histopatológico. 